\title{
The Euro-Mediterranean Free Trade Area: an Evaluation on the Eve of the (Missed) Deadline
}

Ferdi De Ville \& Vicky Reynaert

Ph.D. Candidates at the Centre for EU Studies, Ghent University.

\section{Introduction}

The Euro-Mediterranean Partnership (EMP), nowadays known as 'the Union for the Mediterranean' (UfM), celebrates this year its fifteenth anniversary. Following the geopolitical turbulence of the fall of the iron curtain, the EMP was created in 1995 to enhance the relations between the European Union (EU) and the Mediterranean Non-Community Countries (MNCs). ${ }^{1}$ It consists of three baskets: a political and security partnership, an economic and financial partnership and a partnership in social, human and cultural affairs. The overall objective of the economic and financial partnership is the creation of an 'area of shared prosperity' through 'the stimulation of the socio-economic development of the MNCs, the improvement of the living conditions of Mediterranean people and through regional integration and cooperation'. With this aim, both the EU and the Mediterranean partners agreed to establish a comprehensive and deep EuroMediterranean Free Trade Area (EMFTA) by 2010. ${ }^{2}$ The European Neighbour-

1. Crawford, B., 2004, Why the Euro-Med Partnership? European Union Strategies in the Mediterranean Region. In: Aggarwal, V.K., Fogarty, E.A. (eds.), EU Trade Strategies: Between Regionalism and Globalism, Houndmills: Palgrave Macmillan.

2. Euro-Mediterranean Conference, 1995, Barcelona Declaration, available at: http://ec.europa.eu/external_relations/euromed/docs/bd_en.pdf. 
hood Policy (ENP), created in 2003, even goes one step further and wants to grant the neighbouring countries 'a stake in the internal market'. ${ }^{3}$ Despite these intentions, the ambitious objective of an EMFTA will not be met this year due to various obstacles on both the side of the EU and the MNCs. ${ }^{4}$

In that respect, this article has two core objectives. First, an overview of the initiatives that have been taken so far in order to reach the establishment of an EMFTA will be discussed and compared with the objectives set in 1995 in the next section. Finding that there is a considerable delay in the initiatives regarding the EMFTA, the second objective of this article is to analyze the underlying reasons for this delay. We will especially focus on the political determinants for the lack of progress, supplementary to the already extensive literature on economic causes. In section 3.1, we will elaborate on difficulties at European side, highlighting the discussions regarding the EMFTA between the European member states and between the European Commission, the Council and the Parliament. Next, this article investigates the relationship between the EU and the MNCs in section 3.2, while in 3.3 we elaborate on the political problems between MNCs that impede the development of intraregional trade in the region, a prerequisite for the establishment of a fully-fledged EMFTA. At last, the influence of other international actors in the Mediterranean area, which stimulates real competition between them and the EU, is discussed in section 3.4. We conclude by offering suggestions to overcome the identified obstacles for the completion of a full EMFTA and to establish an inter-regional partnership.

\section{An evaluation of the EMFTA anno 2010}

The last fifteen years, some important research has been conducted on the EMFTA and on the question how we can evaluate the development of a free trade area. Several studies have focused on so-called 'outcome' indicators, and looked at the evolution of trade between the EU and MNCs or trade among MNCs. These studies generally found that trade between the EU and the Mediterranean region became less restrictive ${ }^{5}$, resulting in more trade between both regions ${ }^{6}$ but that trade among MNCs stays rather limited. ${ }^{7}$ However, it is rather difficult to evaluate the impact of the EU through the EMP/ENP on this evolution in trade,

3. European Commission, European Neighbourhood Policy: Strategy Paper, COM (2004) 373, p. 14.

4. $8^{\text {th }}$ Union for the Mediterranean trade ministerial conference, 2009, Conclusions, available at: http:// ec.europa.eu/external_relations/euromed/conf/conclusions_trade_ministerial_en.pdf

5. Hoekman, B., 2007, Regionalism and development: the European Neighbourhood Policy and integration à la carte, Journal of International Trade and Diplomacy, 1, 1, p. 7.

6. Gandara, P., Büge, M., The European Union's trade policy towards the Southern Mediterranean: coherence or chaos?, Go-Euromed Working Paper, 6, 1, p. 6.

7. El-Rayyes, T., 2007, Trade and Regional Integration between Mediterranean partner countries, Go-Euromed Working Paper, 8, 10. 
as also the agreements in the WTO, reforms in the MNCs and international and endogenous economic factors played an important role here. ${ }^{8}$ Other studies were mostly interested in the impact of the EU's measures regarding trade on the economies of MNCs, like for example the sustainability impact assessment (SIA) the European Commission itself ordered. This study found that both in the EU as in the Mediterranean, a rise of economic welfare due to the establishment of the EMFTA can be expected, but that there might be negative social and environmental impacts if no additional measures are taken, like an increase in unemployment. ${ }^{9}$ Contrary to these studies that mainly deal with the outcome and impact of the EMFTA and therefore focus on economic factors, this article will examine the political causes of the slow pace in the establishment of the EMFTA. Therefore, the objectives set in 1995 will be compared with the actual achievements, and the focus will be on 'output' indicators, i.e. the free trade arrangements in place at the moment.

As outlined by the Barcelona Declaration, the objective of a deep and comprehensive EMFTA was to be reached gradually. ${ }^{10}$ We identify three steps in this process, which are not necessarily sequential but can be pursued simultaneously. First, the conclusion of bilateral free trade agreements (FTAs) between the EU and individual MNCs was projected, covering tariff and non-tariff barriers to trade in manufactured products and progressively liberalizing agricultural products and services with due regard to multilateral trade negotiations. Second, regional trade cooperation was envisaged through the conclusion of FTAs among MNCs. The Barcelona Declaration did not specify explicitly how these bilateral agreements would then lead to a Free Trade Area. However, it emphasized the importance of rules of origin and of other non-tariff barriers as technical standards, intellectual property rights and competition as an implicit important third step to complete the EMFTA. ${ }^{11}$ In this section, we will glance through these three steps and evaluate the progress made.

Following ${ }^{12}$ the Barcelona Declaration, Euro-Mediterranean Association Agreements (EMAAs) have been signed and entered into force with Tunisia (1995; 1998), Israel (1995; 2000), Morocco (1996; 2000), Palestinian Authority (1997; 1997), Jordan (1997; 2002), Egypt (2001; 2004), Lebanon (2002; 2003) and Algeria (2002; 2005). With Syria, the agreement was initialled in 2004. At that time, the Council of the EU however refused to sign the agreement due to

8. Hoekman, 2007, p. 7.

9. SIA-EMFTA Consortium, 2007, Sustainability Impact Assessment of the Euro-Mediterranean Free Trade Area, Final Report, pp. 15-16

10. Euro-Mediterranean Conference, p. 4.

11. Euro-Mediterranean Conference, p. 5.

12. In the case of Tunisia and Israel: preceding. 
the difficult political situation in the country. In 2009, relations between Syria and especially France were restored after diplomatic efforts of Syria to get out of its international isolation. Following the opening-up of the relations, the Swedish presidency invited Syria in October 2009 to sign the in 2004 negotiated association agreement, an offer the country refused as it wanted more time to examine the potential impact of the agreement on its economy. ${ }^{13}$ Also with Libya, there are no contractual relations for the moment, a consequence of the sanctions the EU put in place in 1999. In 2004, sanctions were lifted, and the EU started talks with the country to enhance the relations. Negotiations for the conclusion of a framework agreement started in November 2008 and are still going on. ${ }^{14}$

The articles of the original EMAAs provided market access for all industrial products, but were still limited regarding access for agricultural products. There was a commitment towards progressive liberalisation, but initially tariffs and contingent protection remained applicable and were listed in a protocol annexed to the agreement. ${ }^{15}$ Similarly, the agreements contained a commitment to liberalisation of trade in services and the right of establishment, but no specific arrangements were made, except for Lebanon and Algeria (see infra). Furthermore, the agreements state that the implementation of EU competition and state rules are to be decided by the association council and there are no binding disciplines on government procurement liberalization. ${ }^{16}$ In general, we can state that, despite the ambitions of the Barcelona Declaration, the arrangements as written in the association agreements are rather limited and mainly cover trade in industrial goods. However, in recent years, there has been made some important progress on trade relations.

Regarding trade in industrial products, the provisions on custom duties have been fully implemented in case of Tunisia. Also Morocco and Israel have entered the last phase of their liberalization process in industrial goods. However, nontariff barriers (NTBs) remain a major problem. To tackle these NTBs, the EU now wants to conclude Agreements on Conformity Assessment and Accreditation (ACAAs) with MNCs and to establish dispute settlement mechanisms for the trade provisions in the EMAAs. ${ }^{17}$ Regarding the former, there is an agreement with Israel in the pharmaceutical sector, and regarding the latter, negotiations

13. Agence Europe, 20 October 2009, p. 6.

14. Agence Europe, 12 November 2008, p. 7. and European Commission, 2010, Overview of FTA and other trade negotiations, available at: http://trade.ec.europa.eu/doclib/docs/2006/december/tradoc_118238.pdf

15. See e.g.: Euro-Mediterranean Agreement, establishing an Association between the European Communities and their Member States, of the one part, and the People's Democratic Republic of Algeria, of the other part, Official Journal of the European Communities, 10.10.2005, L265.

16. Hoekman, 2007, p. 6.

17. Lannon, E., 2008, Towards a Union for the Mediterranean: progress and challenges in economic and trade relations, Briefing paper for European Parliament's Committee on International Trade, pp. 3-7. 
are already initialled with Jordan (2009), Lebanon (2009), Morocco (2009) and Tunisia (2008). ${ }^{18}$

In 2005, the Council decided to open the negotiations on the liberalization of agricultural products with MNCs. The developments at the international level stimulated this consideration of more far-reaching opening of market access at European side. During the Uruguay (1986-1994) and Doha (2001-ongoing) Round of WTO negotiations, the EU already had to make some important concessions regarding agricultural trade. In anticipation of a further increase in import of agricultural products from third countries, the EU reformed its Common Agricultural Policy (CAP) in 2003 and 2004. This also enabled the EU to make some important concessions regarding free trade in agricultural products with MNCs. ${ }^{19}$ Moreover, due to the developments at the international level and without additional market access commitments by the EU, MNCs like Morocco and Tunisia would be faced with loss of preferential agricultural access to the EU market, a phenomenon called 'preference erosion'. ${ }^{20}$ As a consequence, agreements on the liberalization of agricultural products have already been closed with Egypt, Jordan and Israel. Negotiations are ongoing with Morocco and Tunisia, but advance with difficulty. Although both countries are in favour of greater market access to the EU, they fear the consequences for their own economies of gradually opening their agricultural markets for EU products ${ }^{21}$. The agreements already in place foresee the abolishing of custom duties to agricultural products listed in the protocols that are traded between the MNCs and the EU.

Regarding trade in services, the Council decided also in 2005 to open negotiations on the liberalization of trade in services and right of establishment with the MNCs. Negotiations were launched with Egypt, Israel, Morocco and Tunisia, and are expected to be concluded in $2010 .^{22}$ While the liberalization of trade in services could bring substantial gains for MNCs without the loss of government revenues associated with tariff liberalization for industrial goods, agreement is hampered by the divergent interests of the EU and the MNCs and the complex regulatory reforms such liberalization entails. While the EU has a comparative advantage in modes 1 (cross-border supply) and 3 (commercial presence) the MNCs have interests in liberalization of modes 2 (consumption abroad) and 4

18. European Commission, 2010, Overview of FTA and other trade negotiations, available at: http://trade. ec.europa.eu/doclib/docs/2006/december/tradoc_118238.pdf

19. Galduf, J., 2005, The Application of the CAP Reform and its Repercussions in the Mediterranean Region, Mediterranean Yearbook 2005, pp. 154-157.

20. Escribao, G., 2006, Multilateral Trade Negotiations and Euro-Mediterranean Trade, Mediterranean Yearbook 2006, pp. 169-171.

21. Hervieu, B., 2007, At the heart of the Euro-Mediterranean challenge: The Agriculture and Food Issue, Mediterranean Yearbook, pp. 206-210.

22. 8th Union for the Mediterranean Trade Ministerial Conference, 2009, Conclusions, available at: http:// trade.ec.europa.eu/doclib/docs/2009/december/tradoc_145575.pdf 
(presence of natural persons). The European member states are reticent to make concessions on mode 4, which discourages the MNCs to grant right of establishment for service providers to European companies. ${ }^{23}$ However, in the EMAAs with Algeria and Jordan, commitments regarding the movement of key personnel (mode 4) as well as commercial presence (mode 3) are included, indicating that such trade-offs are possible (see infra). ${ }^{24}$

The second pillar of the EMFTA is the promotion of the conclusion of FTAs among MNCs. Regional integration between MNCs is important to limit the so-called potential 'hub-and-spoke effect' of the conclusion of EMAAs: the risk that investors will choose to invest in the EU (the hub) and then export to the Arab countries (the spokes), leading to few foreign direct investments (FDIs) in the Mediterranean necessary for its economic development. ${ }^{25}$ It has proven to be rather difficult to stimulate FTAs among the MNCs, notwithstanding some important initiatives. In 1997, eighteen Arab countries (including the Gulf countries) signed the agreement establishing a Greater Arab Free Trade Area (GAFTA). As a reaction to this faltering process and spurred on by the EU, Egypt, Jordan, Morocco and Tunisia signed in 2004 the Agadir Agreement for the Establishment of a Free Trade Zone between the Arabic Mediterranean Nations, that is open to other countries in the region which have an Association Agreement with the EU. ${ }^{26}$ The Agadir Agreement covers trade in industrial goods, agricultural products and services. However, the initialization of the agreement had to be postponed until 2007 because certain provisions on agriculture conflicted with the US-Morocco FTA. An important aspect of the Agadir Agreement is that it applies EU rules of origin (see infra). Furthermore, bilateral FTAs are in place between Israel and Jordan and between Turkey and Egypt, Israel, Morocco, the Palestinian Territories, Syria and Tunisia.

This far from complete regional economic integration among the MNCs naturally prevents the regionalization of the FTAs, which we identified as the third and final step towards an EMFTA. However, in expectation of FTAs connecting (all or more) MNCs, steps have already been taken that should facilitate the free movement of goods in the entire EMFTA by the establishment of a system of Pan-Euro-Mediterranean cumulation of origin. ${ }^{27}$ This proposal has been ap-

23. The right of establishment is not mentioned in the Istanbul Framework Protocol, the basis for negotiations regarding trade in services and the right of establishment.

24. Hoekman, B., Özden, C., 2009, The Euro-Mediterranean Partnership: Trade in Services as an Alternative to Migration? World Bank Policy Research Paper, 5049.

25. Hoekman, B. and J. Zarrouk (eds.), 2000, Catching up with competition: trade opportunities and challenges for Arab countries, p. 286.

26. Wippel, S., 2005, The Agadir Agreement and Open Regionalism, EuroMeSCo paper, 45.

27. This means that products which have obtained originating status in one of the 42 countries may be added to products originating in any other one of the 42 countries without losing their originating status within the Pan-Euro-Med zone. However, this diagonal cumulation is conditional: countries of the zone can only cumulate 
proved by the Council on 11 October 2005 and is currently being implemented. It is applied to the four members of the Agadir Agreement and Israel. ${ }^{28}$

Overall, we can state that the pace and scope of the progress towards the establishment of the EMFTA has been disappointing by not realizing fully the objective of a fully-fledged free trade area set in 1995. Although the last five years some important decisions have been taken at European side, e.g. the opening of negotiations in agricultural products and services, there are still some important obstacles to be overcome regarding these sectors. Besides incomplete liberalization between the EU and the MNCs, also regional integration among the MNCs leaves much to be desired. This led the European Parliament rightly to conclude that the Free Trade Area is 'far from being attainted'29 and the Union for the Mediterranean Trade Ministerial Conference to adopt a 'Euromed Trade Roadmap beyond 2010'. In the following sections, we will try to explain the observed slow pace of progress and major obstacles in reaching a full-fledged EMFTA.

\section{Explanations for the slow and incomplete establishment of EMFTA}

\subsection{The EU as an internally conflicted and compartmentalized trade persona}

A first element that contributed to the difficulties in installing a deep and comprehensive EMFTA are the different positions of the European actors regarding the idea and the modalities of an EMFTA with the Mediterranean region. Before negotiating with third countries, there has to be found an internal agreement on the EU's negotiating position between the European institutions (mainly the Commission and the Council) and between the member states. But the European institutions have different positions on the EMFTA due to their different competences, and the member states have different preferences regarding free trade due to their different internal economic and political situations. As a consequence, the EU's multilevel governance structure and its nature of being

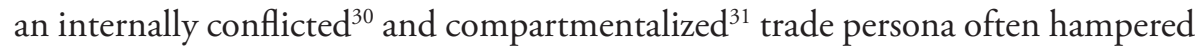
the European actors in finding a common position regarding concessions to be made to MNCs on the road towards a full and comprehensive EMFTA, as the following paragraphs will illustrate.

originating status if they have free trade agreements between them (see http://ec.europa.eu/taxation_customs/ customs/customs_duties/rules_origin/preferential/article_783_en.htm).

28. Lannon, E., Martin, I., 2009, Report on the Status and Progress of the Euro-Mediterranean Partnership: Survey of Experts and Actors on the Euro-Mediterranean Partnership, Barcelona, IEMed, p. 18.

29. Agence Europe, 27 November 2009, p. 1.

30. Meunier, S., Nicolaïdis, K., 2006, The European Union as a Conflicted Trade Power, Journal of European Public Policy, 13, 6, pp. 906-925.

31. Pilegaard, J., 2009, ... and Never the Twain Shall Meet? An Institutionalist Perspective of EU Trade and Developmental Policies in the Context of the EPA Negotiations. In: Faber, G., Orbie, J. (eds.), Beyond Market Access for Economic Development: EU-Africa Relations in Transition, London, Routledge. 
Although the idea of the gradual establishment of an EMFTA was already discussed in the seventies in the context of the Partnership and Cooperation Agreements (PCAs), the idea was laid back on the European table by Morocco in 1992. This idea was welcomed by the European Commission, and by Spain, which hoped that the instalment of the EMFTA would unblock the negotiations on the EEC-Moroccan fisheries agreement, an agreement by which Spanish fishermen would have access to Moroccan fishery grounds. However, the European Parliament was initially not in favour of the free trade area. Because it had no formal competence regarding FTAs, the agreement would diminish its influence in European-Moroccan relations. Nevertheless, the European Council agreed in principle with the idea of the gradual installation of a free trade area between the European Community and all Maghreb countries, although not all European member states were in favour of explicitly stating the objective of a free trade area in the declaration. ${ }^{32}$ Only, later on, with the launch of the Barcelona Process in 1995, all European actors agreed that the establishment of an EMFTA would be one of the most important objectives in Euro-Mediterranean relations.

Also the discussions within and between European institutions regarding the modalities of the EMFTA proved to be rather difficult, especially with regard to trade in agricultural products and the free movement of persons. First of all, regarding trade in agricultural products, there was an important cleavage noticeable within the Commission in the nineties, where the Commissioner for external relations with the Mediterranean was willing to make some important concessions regarding trade in agricultural products. However, he met with resistance from the Commissioner for agriculture, who planned a reform of the Common Agricultural Policy (CAP) and considered that the time was not yet ripe to make already concessions towards third countries. Both commissioners often cut clean across each other, although they always managed to find a compromise. ${ }^{33}$ This compromise had then to be approved by the member states. Regarding agricultural products, there were discussions with the southern member states, that were under the pressure of farm lobbies to protect their agricultural products markets. As the southern member states were rather reticent regarding market access, they suggested to compensate the Mediterranean neighbours by providing them a larger amount of financial assistance. This caused discussion with the northern member states like Germany, which were concerned about the cost that this would bring for the European budget, especially because they were net contributors to the budget. ${ }^{34}$ 
During all negotiations with MNCs on agricultural products, the Commission was confronted with the resistance from Southern member states. However, due to its unique position of negotiator in trade issues, the European Commission has some important power in deciding on European concessions and deals it can arrange. In negotiations on the FTAs with the Mediterranean, the Commission did not doubt to use this power against the member states (as well as against third countries). As a consequence, tensions arose between the Commission and the Council about the distribution of their competences. The latter accused the Commission of going beyond its negotiating mandate, and one member state even wanted to intervene in the negotiations with the MNCs. This made the discussions highly politicized, and caused delays in the negotiations. ${ }^{35}$ Due to the developments at the international level and the reform of the CAP (see supra), the positions of the European actors regarding trade in agricultural products eventually merged, although the North-South cleavage between the Northern and the Southern member states regarding the modalities of the concessions stayed in place.

Second, there were similar cleavages noticeable in the positions of the European actors regarding the temporary movement of natural persons providing services (GATS mode 4), the presence of natural persons. The European Commission is prepared to make concessions towards MNCs in this domain. With the launch of the ENP in 2003, it even proposed to extend the limited provisions for workers to free movement for all persons from neighbouring countries. ${ }^{36}$ However, the problems of the EU to make concessions on mode 4 relate to the sensitivity of the member states towards labour market opening and immigration. Especially the southern member states are reticent, as they would be the first to be confronted with workers and migrants from the Mediterranean. And while the authority to negotiate on the liberalization of trade in goods and services lies with the European Commission, migration is the reserved domain of the member states, enabling them to veto any agreement on the free movement of persons. This shows that the European actors were and still are divided on some important modalities of the EMFTA.

\subsection{The relationship between the $E U$ and the $M N C$ s}

An important consequence of the EU's internally conflicted and compartmentalized nature as a trade persona is the lack of incentives the EU can offer towards MNCs. After a difficult internal European compromise has been agreed, it is almost impossible to deviate from this position during negotiations with third

35. Gomez, R., 2003, Evaluating the Euro-Mediterranean Partnership. Aldershot, Ashgate, p. 59.

36. European Commission, Wider Europe - Neighbourhood: A New Framework for Relations with our Eastern and Southern Neighbours, COM (2003) 104, p. 10. 
countries. Although most MNCs are strong advocates of further liberalization of trade in agricultural products and free movement of persons, they often do not have considerable bargaining power to provoke concessions from the EU. Countries like Morocco and Tunisia export almost $80 \%$ of their products to the EU, meaning that the EU is their most important trading partner, while the Mediterranean as a region is only the fifth trading partner of the EU. ${ }^{37}$ This dependency is intensified by the fact that the MNCs do not succeed in reaching a common bargaining position due to mutual problems (see 3.3). Also the institutional infrastructure of the EMP made it rather difficult for the MNCs to act as one bloc towards the EU. ${ }^{38}$ As argued by Gomez and as shown above, most concessions made by the EU are therefore mainly the consequence of factors outside the Barcelona Process, rather than an admission to Mediterranean demands. ${ }^{39}$

Nevertheless, some Mediterranean partners, and then especially Algeria and Syria do have a considerable amount of bargaining power in their relations with the EU due to their status as energy producers. Algeria and Syria can play an important role in the diversification strategy of the EU to diminish the gas dependency of Russia. Moreover, Algeria is also an important partner for the EU in the fight against illegal immigration and terrorism. Especially Algeria is willing to use this bargaining power to provoke more concessions from European side, particularly regarding the association agreement and free movement of persons. Although Algeria signed an association agreement with the EU that came into force in September 2005, its general feeling is that the agreement until now only had negative consequences for the country. The country felt especially disappointed about the commitments made on European side. Moreover, the minister for trade also stated its disappointment about the lack of support of the EU on the efforts of Algeria to join the WTO. Therefore, it asked the review of the current association agreement. ${ }^{40}$ Similarly, also the Syrian government expressed its doubts about the advantages of the future association agreement with the EU. It delayed the signature of the agreement until it has more clarity about the effects on its economy. ${ }^{41}$ This shows that the EU has problems convincing some of its most important trading partners about the potential benefits of the EMAA and the EMFTA.

37. Bouzeran, A., 2007, The European Union and its ten Mediterranean partner countries: growing trading links. Luxembourg, Official Publication of the European Communities, pp. 4-6.

38. Furness, M., Gandara, P. And A. Kern, The Political Economy of Euro-Mediterranean Governance, Report for GO-EuroMed Brussels Conference, 27-28 November 2008, p. 12.

39. Gomez, R., 2003, Evaluating the Euro-Mediterranean Partnership. Aldershot, Ashgate, p. 60.

40. Agence Europe, 3 February 2010, p. 6.

41. Agence Europe, 20 October 2009, p. 6. 


\subsection{Differences among the MNCs}

Another important prerequisite for the establishment of a full EMFTA, is the conclusion of FTAs among the MNCs. However, until now, the EMP and the commercial negotiations in particular have witnessed a hub-and-spoke relationship dominated by the EU (see supra). The MNCs have not succeeded in integrating their economies. Their intraregional trade still stands at very low, prohibitive levels. This frightens off international investors. As a consequence, MNCs still hold a very low share of global FDIs, although FDIs are considered as necessary to stimulate economic development.

Integration is slow for economic as well as political reasons. Economically, MNCs have rather similar factor endowments and consequent comparative advantages both for industrial and agricultural products. ${ }^{42}$ This makes regional integration sensitive, as it exposes their industries to greater competition from each other in the short term. Combined with the limited absorption capacity of the MNCs and the proximity of the EU, this makes extra-regional trade more attractive than intra-regional trade and, consequently, hampers regional integration. ${ }^{43}$

In addition, scholars also believe that a certain level of 'mutual' trust between countries is needed in order to have regional cooperation and integration. This mutual trust has to be reached through political cooperation. However, this political cooperation among MNCs has proven to be very difficult. The MNCs clearly lack mutual understanding and trust in general to generate regional cooperation and integration. Particularly the Arab-Israeli conflict prevents the establishment of a common front. The still tense relationship between Morocco and Algeria, poisoned by their decennia-old conflict on the Sahara and the conflict in Lebanon are also barriers to a more united front among MNCs. ${ }^{44}$

\subsection{The influence of other international players}

Besides the problems discussed above, also the presence of other important international players and the challenges as well as chances for the European Mediterranean policy this implies has to be factored in. A first important actor that has to be reckoned with is the United States. The US is a Mediterranean power thanks to its power on the world stage and its historical involvement in parts of the region, most notably in the Israeli-Palestinian conflict. For the United States, the region is of less importance than for the EU. In contrast to the European

42. SIA-EMFTA Consortium, p. 14

43. El-Rayyes, T., 2007, The Political Economy of Governance in the Euro-Mediterranean Partnership. GoEuroMed Working Paper, available at http://www.go-euromed.org/documents/working_paper/WP0711_El_ Rayyes_Trade\%20and\%20Regional\%20Integration\%20between\%20MPCs.pdf.

44. Escribao, T., 2000, Euro-Mediterranean versus Arab integration: Are they compatible? Conference Paper, available at: http://www.uned.es/deahe/doctorado/gescribano/apiart.pdf, p. 7. 
approach, therefore, US engagement with MNCs is bilateral or sub-regional (instead of regional) and issue-area driven (instead of holistic). This means European interests are sometimes shared with the US, such as on security in general and weapons of mass destruction in particular, and thus its power to reach its objectives on such issues reinforced. But in the meantime, the selective engagement of the US may distort its more holistic intentions, the stimulation of regional integration in particular. Also on the economic and trade front, the US has been active in the Mediterranean region. In 2000, the US concluded a free trade agreement with Jordan, while in 2004, the US and Morocco signed an FTA. The US has planned a Middle East Free Trade Area by 2013. ${ }^{45}$

Another important player is the Gulf Cooperation Council (GCC -Bahrain, Kuwait, Oman, Qatar, Saudi Arabia and United Arab Emirates). ${ }^{46}$ These countries have large financial surpluses thanks to their oil exports. Traditionally, they invest these surpluses in industrialized countries (mostly the US and Europe) but increasingly, their FDI flows to the neighbouring Mediterranean, with concentration in the Mashreq. Through the GAFTA, the GCC countries are establishing a common market with the MNCs, again possibly interfering with the EMFTA. While it is difficult to assess the impact of these trade policies of the US and the GCC on the EMFTA, such competitive liberalisation adds complexity to the creation of a regional free trade area because of, inter alia, competing rules of origin, technical, safety and health standards. This has already been witnessed in the problems the US-Morocco FTA caused for the implementation of the Agadir Agreement. The 'preference clause' for agricultural products in this FTA that will afford US exporters of such products any better market access that Morocco gives other trading partners may also complicate EU-Morocco and regional trade integration in the future.

While Russia and China are not active on the trade policy front yet, their commercial and political presence is important for EU Mediterranean policy too. Russia is interested in the Mediterranean because of well-defined economic interests, as well as because of broader strategic goals. ${ }^{47}$ Lastly, China is ever more present in the MNCs. North African countries have become major suppliers of raw materials and energy for hungry Chinese industries. ${ }^{48}$ Simultaneously, China has become a major supplier of, and investor in, MNCs. China is also an impor-

45. Through Trade and Investment Framework Agreements (TIFAs), Bilateral Investment Treaties (BITs), comprehensive Free Trade Agreements (FTAs). Bilateral FTAs with Israel, Jordan, Morocco, Bahrain, and Oman have already entered into effect. See http://www.ustr.gov/trade-agreements/other-initiatives/middle-east-freetrade-area-initiative-mefta.

46. Baabood, A., 2009, The Growing Economic Presence of Gulf Countries in the Mediterranean Region. In: Med.2009: Mediterranean Yearbook, pp. 203-209.

47. Makarychev, A.S., 2009, Russia in the Mediterranean Region: Resources of Influence. In: Med.2009: Mediterranean Yearbook, pp. 169-172.

48. Lafargue, F., 2008, China in North Africa. In: Med.2009: Mediterranean Yearbook, pp. 64-68. 
tant competitor of MNCs on the European market, for example, in textiles. All these initiatives and evolutions have to be reckoned with in European Mediterranean economic policy.

\section{Conclusion}

Although there has been made significant progress in the instalment of the EMFTA, like the opening of negotiations on agricultural products and services or the conclusion of the Agadir Agreement, a combination of factors has hampered the completion of an actual deep and comprehensive free trade area this year, as was foreseen in the Barcelona Declaration fifteen years ago. First of all, the EU's nature of being an internally conflicted and compartmentalized trade persona has hindered the EU of providing substantial incentives for MNCs, like free trade in agricultural products or free movement of persons. Second, as a consequence of this difficulty to provide incentives, the EU fails to convince some of its most important partners like Algeria or Syria of the benefits of the EMFTA. Most of the MNCs did not have a considerable amount of bargaining power to persuade the EU to comply with its promise of the establishment of a fully-fledged FTA. Moreover, MNCs did not succeed in cooperating and integrating economically due to political divergences, but also because they have similar economic production structures. Therefore, the relations between the EU and the Mediterranean still can be best caracterized as a 'hub-and-spoke' relation instead of an interregional partnership. This impedes the establishment of an EMFTA. In addition, the EU meets with competition from other international actors, like the US, Russia, China and the Gulf countries. Their economic interests in the region, and in case of the US and the GCC their own trade initiatives, interferes with the EU's efforts to create a free trade area with the Mediterranean.

However, our review also shows that there are attainable solutions for all of the identified problems. First of all, liberalisation between the EU and MNCs can be enhanced by further negotiating trade-offs that are economically beneficial and politically feasible both for the EU and MNCs. Agreement whereby the EU goes further in liberalising agriculture and mode 4 of trade in services in exchange for liberalisation of investment and further economic and administrative reform in line with the EU acquis on the side of MNCs should be possible. However, this seems to a large degree dependent upon flanking and supporting measures within the EU and, supported by the EU, within the MNCs and necessitates a more equal and confident relationship between the EU and the MNCs. Second, to create the right context for such a true inter-regional partnership, two things should be done. On the one hand, the dependency relation between the EU and the Mediterranean has to be moderated by making changes in the institutional structure of the EMP. The Union for the Mediterranean provides an increase in 
co-ownership of the partnership by the establishment of a co-presidency and the setting-up of a joint secretariat and a joint permanent committee. However, it will depend on the will of the political actors at both sides of the Mediterranean if these new institutions can increase ownership, and if it can stimulate cooperation among MNCs. On the other hand, among MNCs intra-regional trade should be enhanced and political cooperation and regional integration encouraged. The EU has to sustain its efforts to find a solution for the political problems in the region, like the dispute on the Western Sahara between Algeria and Morocco, but especially to help find a solution for the conflict between Israel and the Arab states. Without a definite settlement for the conflict in the Middle East, regional integration and a fully-fledged free trade area with Israel as a member is an illusion. Third, in addition, the EU should also sustain and strengthen its efforts to address the remaining economic non-tariff barriers towards inter-regional integration. The establishment of a system of Pan-Euro-Mediterranean cumulation of origin and the negotiation of ACAAs are steps in the right direction. 